\title{
BIOLOGY AND FISHERY OF BARRED SPINY EEL, MACROGNATHUS PANCALUS HAMILTON
}

\author{
Vettath R. SURESH* , Benoy K. BISWAS, Gobi K. VINCI, Krishna MITRA, \\ Ardhendu MUKHERJEE \\ Central Inland Fisheries Research Institute, Barrackpore, Kolkata, \\ West Bengal, India
}

Suresh V.R., Biswas B.K., Vinci G.K., Mitra K., Mukherjee A. 2006. Biology and fishery of barred spiny eel, Macrognathus pancalus Hamilton. Acta Ichthyol. Piscat. 36 (1): 31-37.

\begin{abstract}
Background. The barred spiny eel, Macrognathus pancalus Hamilton 1822 (known also as the striped spiny eel) has high food- as well as ornamental value in India and its neighbouring countries. The natural resources of this species are declining due to over exploitation and habitat changes. The aim of this study was to provide necessary inputs on food habits, reproductive biology, and fishery of the species for artificial propagation programs and fisheries guidelines for conservation of its natural populations.
\end{abstract}

Materials and Methods. Fish samples were collected monthly, for a period of 12 months, from an oxbow lake, situated in the Ganga River basin, India, during June 2004-May 2005. Food habits, reproductive biology, length-weight relation, fishery resource status, asymptotic length $\left(L_{\infty}\right)$, length at maturity $\left(L_{\mathrm{m}}\right)$ and length at maximum possible yield $\left(L_{\mathrm{opt}}\right)$ for the species were studied.

Results. The fish subsisted mainly on insect larvae. Fecundity range was 227 (fish: $10.7 \mathrm{~cm}$ and $5.03 \mathrm{~g}$ ) to 8310 (fish: $17 \mathrm{~cm}$ and $30.31 \mathrm{~g}$ ). Length at first maturity calculated through maturity curve was 10-11 cm (males) and $11-12 \mathrm{~cm}$ (females) in total length. The breeding period was within March-September. The regression model fitted for length and weight of the fish was $\log W=3.3224 \log L-6.0793, R^{2}=0.9094$ for male; $\log W=3.3378 \log L-6.0716, R^{2}$ $=0.9183$ for female. The exponent ' $b$ ' for male and female varied significantly from ' 3 ' indicating allometric growth pattern. The relation of fecundity with total length and weight of the fish was $\log F=2.9574 \log L-3.2055, R^{2}=0.3728$ and $\log F=0.9684 \log W+2.0934, R^{2}=0.4716$. Immature specimens dominated in the catch. The estimates obtained for $L_{\infty}=18.8 \mathrm{~cm}$ (s.e. range $\left.15.9-22.3 \mathrm{~cm}\right), L_{\mathrm{m}}$ male $=10.8 \mathrm{~cm}$ (s.e. range $\left.7.7-15.1 \mathrm{~cm}\right), L_{\mathrm{m}}$ female $=12.3 \mathrm{~cm}($ s.e. range $9.3-16.3 \mathrm{~cm}$ ) and $L_{\mathrm{opt}}=11.3 \mathrm{~cm}$ (s.e. range 9.6-13.4 cm). Biomass of the species in experimental fishing was high during October-January, which was also the period when immature specimens were lowest.

Conclusion. Closed or less intense fishing for the species during March-September and capture of only specimens above $14 \mathrm{~cm}$ length would help conservation of the natural stock of the fish in the wetland.

Keywords: biology, fishery, Macrognathus pancalus, barred spiny eel, striped spiny eel, food habits, length-weight relation, conservation

\section{INTRODUCTION}

The barred spiny eel, Macrognathus pancalus Hamilton, 1822 (known also as the striped spiny eel) is one of the common species of fishes of the family Mastacembelidae found in Asia. The species is distributed to India, Pakistan, Bangladesh (Talwar and Jhingran 1991) and Nepal (Froese and Pauly 2006). It inhabits slow and shallow waters of rivers in the plains as well as estuaries and a variety of other freshwater habitats (Talwar and Jhingran 1991). M. pancalus plays an important role in meeting the nutritional requirements of people in India. In northern, eastern and north-eastern parts of India, the fish particularly has very high demand, especially when sold alive and fetch higher market price (INR 60-80 per kg) than major carps (INR 40-60 per kg). The species has also gained importance for its ornamental value as an indigenous aquarium fish in India and is being exported to America, Europe, and other Asian countries (Sugunan et al. 2002, Tripathi 2004). In having bottom living habit, the fish is generally caught in dragnets and cast nets. Local contraptions like Khojni jal and bottom-set traps are exclusively used to catch bottom living fishes including M. pancalus from the wetland

\footnotetext{
*Correspondence: Dr V.R. Suresh, Senior Scientist, Floodplain wetlands Division, Central Inland Fisheries Research Institute, Barrackpore, Kolkata700 120, West Bengal, India, phone. (+91 33) 25921190 (91) ext. 213 (O), fax: (+91 33) 25920177, mobile phone: (+919830108768, e-mail: sureshvr64@yahoo.com
} 
where the study was conducted. Amongst these, Khojni $\mathrm{jal}$ is the most prominent gear in which M. pancalus is predominantly caught from the wetland. There is virtually no information on the fishery and resource status of the fish for management and conservation. The natural populations of this species are fast declining in India, as perceived from dwindling market arrivals, due to habitat modification and over exploitation. The entire demand for this fish in India is met through collection from the wild. Unregulated exploitation might endanger their wild populations. The species is not listed in IUCN Red Data Book (Anonymous 2006). Nevertheless, it is included under 'Lower Risk-near threatened' category in India (Anonymous 1998).

Biological and fisheries investigations, carried out on this species in the past, are on sexual dimorphism (Swarup et al. 1972), maturity and fecundity (Karim and Hossain 1972), and food and feeding habits (Serajuddin and Ali 2005). Talwar and Jhingran (1991) described the systematics and distribution of the species. Dutta (1989/1990), Serajuddin and Mustafa (1994) and Serajuddin et al. (1998) investigated the food and feeding habits. Serajuddin (2004) studied the intra specific diversity of a closely related species, M. armatus. Considering the importance of this species in nutritional, economic and biodiversity point of view, its conservation and propagation are being considered through fisheries regulation and artificial breeding. Nevertheless, comprehensive information on the biology and resource status of M. pancalus is not available to provide necessary inputs to these programs. Therefore this study was carried out on the biology of the species (food habits, reproductive characteristics, and length-weight relation), fishery and resource status in an oxbow lake, in the Ganga River basin, India.

\section{MATERIALS AND METHODS}

Samples of $M$. pancalus Hamilton, 1822, for biological studies, were collected monthly, for a period of 12 months, from local fishermen while they were caught from an oxbow lake, situated in the Ganga River basin at North 24 Parganas district of West Bengal, India, during June 2004-May 2005. After bolting off water from their body the total length, from the tip of the snout to the posterior end of caudal fin was measured to the nearest $0.1 \mathrm{~cm}$. The weight was recorded on an electronic balance sensitive to $0.001 \mathrm{~g}$. The specimens were then preserved in $10 \%$ formalin for subsequent analysis. Sexes were separated by external morphology on larger specimens (Swarup et al. 1972) as far as possible and also by examining gonads after dissection.

Guts of the specimens were dissected out and analyzed for food components. The alimentary tract consisted of a narrow oesophagus leading to a spindle-shaped stomach, which narrows down to the U-shaped duodenum, followed by two pyloric caeca and intestine. Two third of the length of the intestine is looped anteriorly, up to half of the length of stomach, before bending towards the anal opening at the posterior end of the body cavity. The food items were identified up to major taxonomic groups. The period of intense feeding of the fish was arrived at by calculating the monthly feeding index (FI) expressed as the number of fishes with food in stomach divided by number of fish examined $\times 100$, as well as following the gastrosomatic index as weight of gut divided by weight of fish $\times 100$.

Sex ratio of the fish was studied using Chi-square test $\left(x^{2}\right)$, following the equation of Fisher (1970), assuming that the ratio of male to female in the population to be $1: 1$. The fecundity was estimated by counting the number of mature ova (opaque and larger in size) from known weights of sub samples collected from the anterior, posterior and middle portions of both the ovaries and calculating the total number of mature ova in the ovary following Grimes and Huntsman (1980). The length at first maturity was worked out for males and females by plotting the condition factor $K$ of male and female against their length groups (Hart 1946). The condition factor $K$ was calculated using the formula, $K=W \times 10^{5} \cdot L^{-3}$, where $W$ is weight of fish, $L$ is the total length of fish, and the number $10^{5}$ is introduced to bring the value near unity. The length at first maturity was also determined directly by plotting the percentage of mature fish against their length. The length at which $50 \%$ of the females were mature (with developed ova in ovaries) was considered as the length at first maturity. To determine the spawning season and breeding periodicity, the ova diameter progression was recorded monthly (an ocular micrometer was used for the measurement of diameter) and by plotting the mean percentage frequency of ova of different diameter in mature ovaries, against different months (Hickling and Rutenberg 1936). Small and transparent ova were considered as immature, medium sized and less transparent were considered as maturing and the large opaque ova were considered mature or ripe. Gonadosomatic index (GSI) was estimated following June (1953). The relation between length and weight of the fish was established following the formula of Le Cren (1951) by transforming into a straight-line equation, $\log W=\log$ $a+b \log L$. The values of $a$ and the exponent $b$ were calculated following Lagler (1956). To see whether the species followed cube law the values of the exponent $b$ was tested against ' 3 ' applying Student's $t$ test.

To assess the fishery status of the species, experimental fishing was carried out using Khojni jal (a net, locally used for catching bottom living fishes), of fixed size, by two fishermen. Khojni jal is made of fine meshed net fitted on a triangular bamboo frame with 3.0-m-wide mouth. One person operates the net, along the bottom of the wetland from a wooden canoe, while another person scare the bottom living fishes in to the net from the opposite side, using an inverted T-shaped bamboo structure having 2.5$\mathrm{m}$-long horizontal bar, then the net is lifted capturing the fishes. A fixed number of five liftings each were made in four randomly selected stations of the wetland at monthly intervals, for one year, except for September, February, and May, when this could not be done due to local inconvenience. The time of collection was fixed during the morning hours. The length, weight, and maturity stages of 
these specimens were recorded separately and the specimens were pooled for other biological studies. The asymptotic growth $\left(L_{\infty}\right)$, length at maturity $\left(L_{\mathrm{m}}\right)$ and length at maximum yield per recruit $\left(L_{\text {opt }}\right)$ were estimated (Froese and Binohlan 2000) using the 'popdynJFB' spreadsheet downloaded from http://www.fishbase.org

\section{RESULTS AND DISCUSSION}

Food habits. A total of 204 guts were analyzed, of this $81.8 \%$ were empty. Serajuddin and Ali (2005) also reported a large number of empty guts in samples $(40 \%-65 \%)$ of the species in their study. The weight of gut contents varied from 0.016 to $0.66 \mathrm{~g}$, of which insect larvae formed $91.27 \%$; annelids $4.85 \%$, and the rest $3.88 \%$ was unidentifiable digested matter. Serajuddin and Ali (2005) recorded aquatic insects, crustaceans, annelids, and small forage fish as major food items and indicated stenophagism (selecting few organisms for diet despite the presence of large number of different organisms in the habitat) in the fish. Similar results were also reported for the closely related species, M. armatus (Dutta 1989/1990, Serajuddin et al. 1998). Insect larvae in the gut contents in this study were dominated by dipterens (Chironomus sp., Tanypus sp., Pentaneura sp., and Chaoborus sp.), followed by trichopterans and ephemeropterans. Among annelids oligochaetes (mainly Tubifex sp., Branchiura sp., and Lumbriculus sp.) were the dominant items. Although the basic feeding habit was same, the dominant food items showed difference in this study from that of Serajuddin and Ali (2005). This might be related to the availability of food materials in the habitat where the fish inhabits as the specimens in their study were mostly of riverine origin, where the food organisms available may be different from that of the wetland in this study. The feeding index and gastrosomatic index of male and female for different months are given separately in Fig. 1. The feeding intensity and gastrosomatic index were high during June-September with the peak being in August, indicating active feeding period. October-December was the period of less intense feeding. Serajuddin and Ali (2005) also reported less intense feeding of the species during October-December, although there were size specific variations.

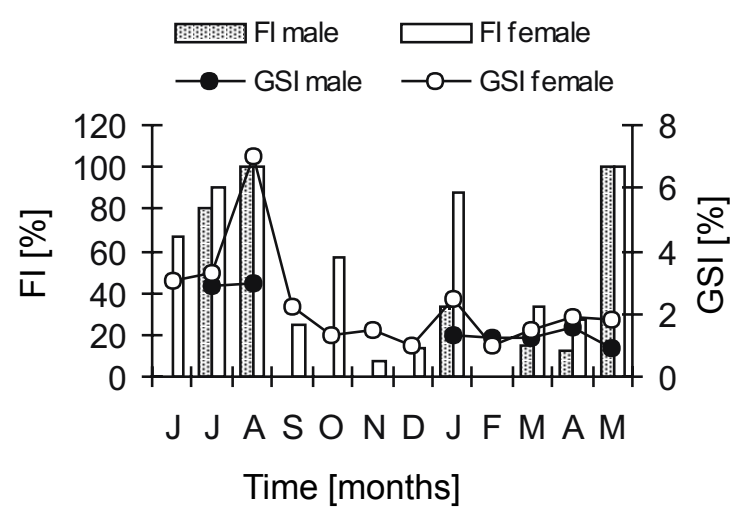

Fig. 1. Monthly variation in the feeding index (FI) and gastrosomatic index (GSI) of male and female $M$. pancalus
Reproductive biology. The sex ratio of the fish showed highly significant (Chi-square, $P>0.01$ ) monthly variation from the expected male : female ratio of $1: 1$. Swarup et al. (1972) found that the sex ratio of the species to be approximately $1: 1$. However, in this study the ratio ranged from $1: 0.59$ to $1: 8.3$. The overall sex ratio for the pooled observations also varied significantly from the expected ratio (Chi-square, $P>0.01$ ), with 2.92 females for every male (Table 1). Males were absent during September-December. Although there can be post-spawning mortality, as in the case of some fishes, the reason for this could not be established in this study. Females were larger in size (mean $12.59 \mathrm{~cm}, 9.43 \mathrm{~g}$ ) than males (mean $9.91 \mathrm{~cm}, 3.79 \mathrm{~g})$. Swarup et al. (1972) also reported similar size difference in the species with females of 10.6 $17.8 \mathrm{~cm}$ and males of 7.2-14 cm length in the population.

The fecundity of the fish ranged from 227 (fish: 10.7 $\mathrm{cm} ; 5.03 \mathrm{~g}$ ) to 8310 (fish: $17 \mathrm{~cm} ; 30.31 \mathrm{~g}$ ), while the relative fecundity range (fecundity per gram body weight corresponding to absolute fecundity) was 45-274. The monthly variation in mean fecundity, calculated as mean of fecundities of monthly samples, is shown in Fig. 2. Fecundity was high during May-August, which falls within the breeding period of the fish as discussed elsewhere in this paper. The regression model of the relation of fecundity with total length and weight of the fish (Table 2) was $\log F=2.9574 \log L-3.2055, R^{2}=0.3728(t=4.816, v$ $=39, P>0.01)$ and $\log F=0.9684 \log W+2.0934, R^{2}=$ $0.4716(t=5.905, v=39, P>0.01)$. Fecundity increased with increase in length and weight of the fish.

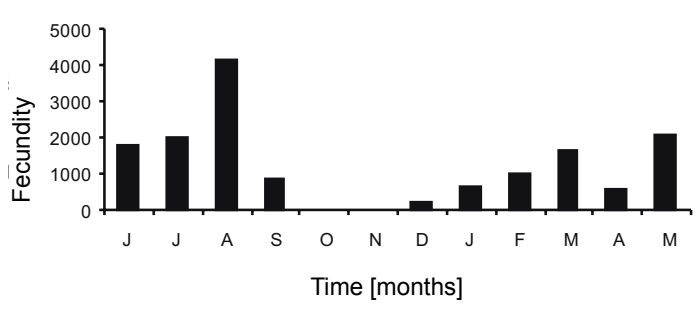

Fig. 2. Mean monthly variations in fecundity of M. pancalus

Length-weight relation, condition factor, and maturity. Length-weight relation helps prediction of potential yield and determination of size at capture for obtaining optimum yield, as these management parameters are directly related to weight of the fish. The relation is also useful in differentiating populations as variations occur in populations of different localities (Le Cren 1951, Chonder 1972). The length-weight equation models established for both the sexes of $M$. pancalus are given separately in Table 2. The regression model fitted for length and weight of male and female yielded significant results $\left(\log W=3.3224 \log L-6.0793, R^{2}=0.9094\right.$ for male; $\log W=3.3378 \log L-6.0716, R^{2}=0.9183$ for female), however the values of the exponent $b$ for male and female varied significantly from ' 3 ' ( $t$ test; $t=24.8, v$ $=49, P<0.01$ for male; $t=48.36, v=146, P<0.01$ for 
Table. 1

Monthly variation in sex ratio (male : female) of $M$. pancalus

\begin{tabular}{|c|c|c|c|c|c|}
\hline Months & Total samples & Male & Female & Sex ratio & Chi-square \\
\hline Jun & 12 & 0 & 12 & - & $12.00^{* *}$ \\
\hline Jul & 16 & 5 & 11 & $1: 2.2$ & 2.25 \\
\hline Aug & 15 & 2 & 13 & $1: 6.5$ & $08.07^{* *}$ \\
\hline Sep & 4 & 0 & 4 & - & $04.00^{*}$ \\
\hline Oct & 14 & 0 & 14 & - & $14.00^{* *}$ \\
\hline Nov & 13 & 0 & 13 & - & $13.00^{* *}$ \\
\hline Dec & 22 & 0 & 22 & - & $22.00^{* *}$ \\
\hline Jan & 28 & 3 & 25 & $1: 8.33$ & $17.29^{* *}$ \\
\hline Feb & 27 & 17 & 10 & $1: 0.59$ & 1.81 \\
\hline Mar & 16 & 7 & 9 & $1: 1.29$ & 0.25 \\
\hline Apr & 31 & 16 & 15 & $1: 0.94$ & 0.03 \\
\hline May & 2 & 1 & 1 & $1: 1$ & 0 \\
\hline Overall & 200 & 51 & 149 & $1: 2.92$ & $48.02^{* *}$ \\
\hline
\end{tabular}

Significant at ${ }^{*} P=0.05$ and ${ }^{* *} P=0.01$

Table 2

Regression models for different variables of $M$. pancalus

\begin{tabular}{|c|c|c|c|c|c|}
\hline Variable & Model & Variable range & $v$ & $R^{2}$ & $P>$ \\
\hline Length-Weight (male) & $\log W=3.3224 \log L-6.0793$ & $\begin{array}{l}L: 80-120 \mathrm{~mm} \\
W: 1.99-7.54 \mathrm{~g}\end{array}$ & 49 & 0.9094 & 0.01 \\
\hline Length-Weight (female) & $\log W=3.3378 \log L-6.0716$ & $\begin{array}{l}L: 85-178 \mathrm{~mm} \\
W: 2.17-30.31 \mathrm{~g}\end{array}$ & 146 & 0.9183 & 0.01 \\
\hline Length-Fecundity & $\log F=2.9574 \log L-3.2055$ & $\begin{array}{l}L: 104-178 \mathrm{~mm} \\
F: 205-8310\end{array}$ & 39 & 0.3728 & 0.01 \\
\hline Weight-Fecundity & $\log F=0.9684 \log W+2.0934$ & $\begin{array}{l}W: 4.15-33.16 \mathrm{~g} \\
F: 205-8310\end{array}$ & 39 & 0.4716 & 0.01 \\
\hline
\end{tabular}

$v$, number of degrees of freedom

female), indicating that the fish did not follow cube law. For a fish, which maintains shape proportion throughout its life, the value of regression coefficient will be ' 3 ', (Varghese 1961, Talwar 1962). Other than ' 3 ', the value indicates allometric growth.

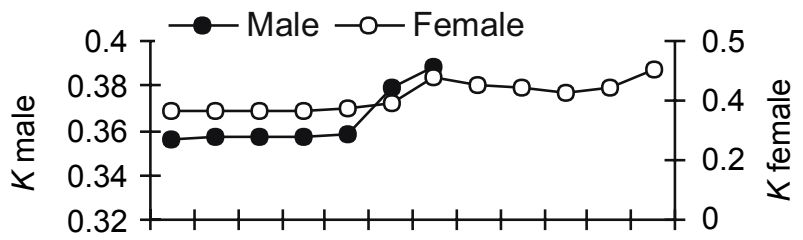

$6 \begin{array}{llllll}6 & 8 & 9 & 1011121314151617\end{array}$

\section{Length [ंcm]}

Fig. 3. Condition factor in relation to different length of male and female M. pancalus
The condition factor $K$ for males and females of the fish in relation to different length groups is shown in Fig. 3. Hart (1946) observed a point of inflexion on a curve showing $K$ with increase in length, which indicated the length at which sexual maturity is attained. This feature was successfully applied in many fishes (Menon 1950, Qayyum and Qasim 1964, Kagwade 1968). There are inflexions on the curve showing $K$ of $M$. pancalus against the length $10-11 \mathrm{~cm}$ for males and $11-12 \mathrm{~cm}$ for females (Fig. 3), indicating the length at first maturity according to Hart (1946). The maturity curve plotted for the fish by direct observation of ovaries and testis also showed that $50 \%$ of the males matured at length $10-11 \mathrm{~cm}$ and females at $11-12 \mathrm{~cm}$ (Fig. 4).

Spawning. The monthly progression of ova diameter frequency is shown in Fig. 5. The diameter of ova ranged from 0.01 to $1.3 \mathrm{~mm}$. The frequency of occurrence of ova of different diameter plotted against different months showed that immature ova $(0.01-0.4 \mathrm{~mm})$ were present in the 


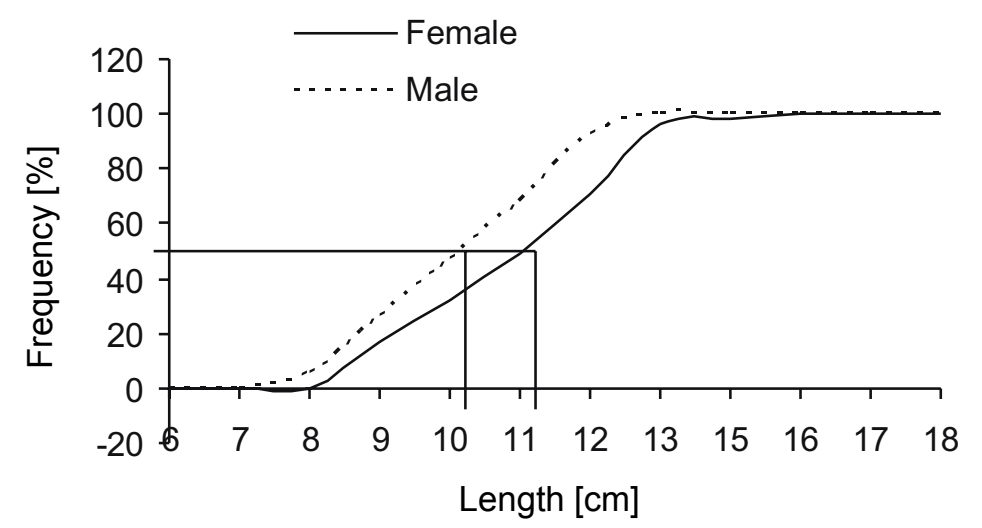

Fig. 4. Percentage occurrence of mature male and female M. pancalus at different lengths

ovaries during December-September. Maturing ova $(0.41-$ $0.8 \mathrm{~mm})$ also showed similar pattern. Ripe ova $(0.81-1.3$ $\mathrm{mm})$ were present during March to September with peaks in May (22.4\%) and August (50.84\%) indicating that the fish might have two peak spawning period. The frequency of maturing and mature ova began to drop from September while these were completely absent during October-November, an indication that the spawning was over. Then again from December-January onwards their frequency began to build up (Fig. 5). The ovaries carried immature (0.01 and $0.4 \mathrm{~mm}$ diameter) and mature ova ( 0.81 to $1.3 \mathrm{~mm})$ separated from each other by maturing ova ( $0.41-0.8 \mathrm{~mm}$ diameter). The breeding period of a fish will be for a definite duration if the mature ova are sharply separated from the stock of immature ova (Hickling and Rutenberg 1936). In this case the mature ova were separated from the immature stock by maturing ova. It is likely that the ova size ranging from 0.81 to $1.3 \mathrm{~mm}$ are the stock of eggs to be shed and the maturing stock will mature subsequently. This indicated that the fish has a long spawning period, which extends from March to September. These results indicated that for captive breeding programs gravid fishes are available in the wild during March-September.

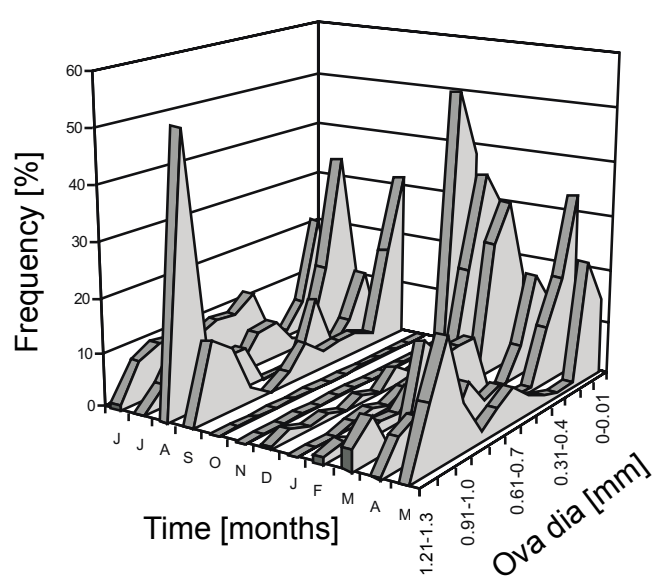

Fig. 5. Monthly progression of ova diameter frequency of $M$. pancalus
The feeding intensity reduced during October-Dece mber, the period of post spawning, as inferred from Fig. 1. The feeding gradually intensified from February onwards and continued to increase until August, the end of breeding period. Serajuddin and Ali (2005) on the same species found that the feeding intensity declined when the fish became ripe, however never discontinued feeding, even during spawning period. Reasons could not be given for this at the moment without specific studies. In the case of females, this study too showed that the fish never discontinued feeding during spawning period. Males however were absent in samples during this period (Table 1).

The monthly variations in gonadosomatic index (GSI) of the male and female fish are shown in Fig. 6. The values of GSI varied from 0.33 to 7.31 for female and 0 to 1.89 for male. Both the values were lower during October-January. From January onwards the values began to rise until July and started to fall then on. This also indicated that the spawning was over by October.

Fishery assessment. The estimate for length at infinity (asymptotic length), $L_{\infty}=18.8 \mathrm{~cm}$ (s.e range 15.9-22.3 $\mathrm{cm}$ ); Length at maturity, $L_{\mathrm{m}}=10.8 \mathrm{~cm}$ (s.e. range 7.7-15.1 $\mathrm{cm}$ ) for male and $12.3 \mathrm{~cm}$ (s.e. range $9.3-16.3 \mathrm{~cm}$ ) for female and length at maximum yield, $L_{\text {opt }}=11.3 \mathrm{~cm}$ (s.e. range $9.6-13.4 \mathrm{~cm}$ ). Although the length at maturity worked out through direct method (Figs. 3, 4) for female is slightly lower $(11-12 \mathrm{~cm})$, than the values estimated following Froese and Binohlan (2000), they fall within the s.e. range of the estimate. Plotting the length frequency data obtained from the fixed gear/effort experimental fish-

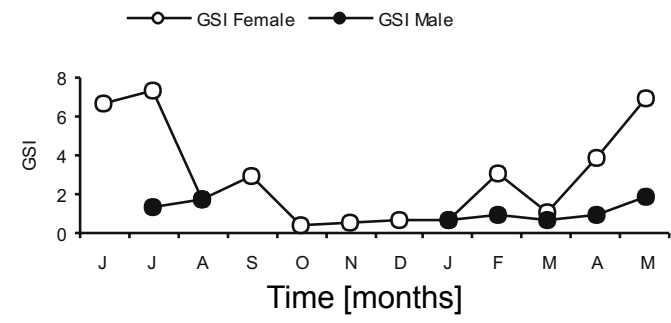

Fig. 6. Monthly variation in gonadosomatic index (GSI) of $M$. pancalus 


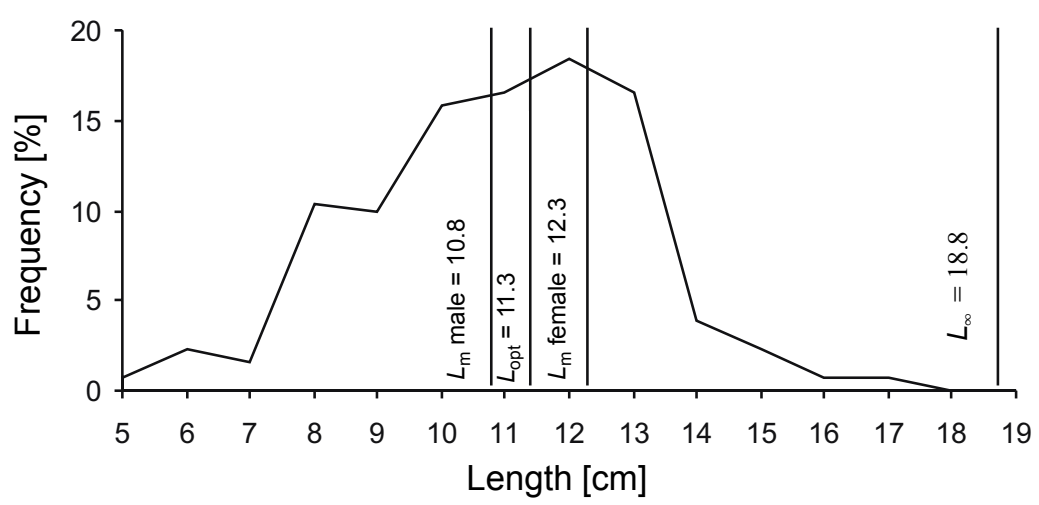

Fig. 7. Length frequency data of $M$. pancalus plotted in a framework of $L_{\infty}, L_{\mathrm{m}}$, and $L_{\mathrm{opt}}$

ing in this study in a $L_{\infty}, L_{\mathrm{m}}$ and $L_{\mathrm{opt}}$ framework (Froese and Binohlan 2000) revealed that $57.3 \%$ male and $75.8 \%$ female $M$. pancalus caught were smaller than their lengths at first maturity indicating growth over fishing. With the $L_{\text {opt }}=11.3 \mathrm{~cm}, 57.3 \%$ of the fishes caught were smaller than the length at maximum possible yield (Fig. 7). The catch of fish at a unit effort of 20 liftings with Khojni jal by two fishermen in different months are shown in Fig. 8. The number of fish caught was maximum during March-April, while the biomass was maximum during October-January (251.6-279.8 g). October-January was also the period when the percentage of immature specimens were lowest in the catch $(0 \%-2.94 \%)$, compared to June-September ( $0 \%-50 \%)$ and February-March (20\%$61.76 \%$ ) as shown in Fig. 8. Immature specimens were maximum in August and March-April. The status of the ovary of the fishes caught during October-January revealed that most of the ovaries were spent (Fig. 5). These results indicated that the most productive fishing period for the species is October-January. Although the length at first maturity obtained for the fish is $12.3 \mathrm{~cm}$, the minimum length recorded for specimens with spent ovaries were $13.5 \mathrm{~cm}$. Hence, closed or less intense fishing during March-September and selective catch of only $13.5 \mathrm{~cm}$ (say $14 \mathrm{~cm}$ ) and above length, would help conservation of
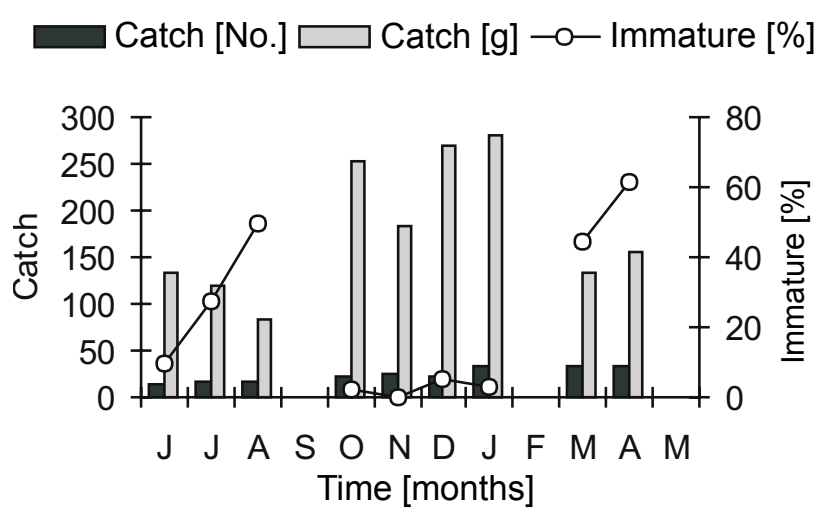

Fig. 8. Catch of M. pancalus during June 2004-May 2005 and percentage of immature fishes in the total catch in numbers the natural stock of the fish, by allowing the fish to breed at least once in their lifetime.

\section{ACKNOWLEDGEMENTS}

We thank Dr. K. K. Vass, Director, Central Inland Fisheries Research Institute (ICAR), Barrackpore, Kolkata for providing necessary facilities to carryout this study. The technical and field help provided by Y. Ali, CIFRI, Barrackpore, is acknowledged. We thank the reviewers of the MS for their valuable suggestions; one of them particularly for suggesting methods for evaluating length frequency data. The study is part of the Central Inland Fisheries Research Institute (ICAR) project No. FW A/7, 'Development of eco-friendly management norms for enhancing fish production in floodplain wetlands of India in relation to their resource characteristics'.

\section{REFERENCES}

Anonymous 1998. Report of the workshop on "Conservation Assessment and Management Plan (CAMP) for Freshwater Fishes of India". National Bureau of Fish Genetic Resources, Zoo Outreach Organization/CBSG, India.

Anonymous 2006. 2006 IUCN red list of threatened species. http://www.redlist.org

Chonder S.L. 1972. Length-weight relationship of mature female Labeo gonius (Hamilton) from the Keetham Reservoir. Journal of the Inland Fisheries Society of India 4: 216-217.

Dutta S.P.S. 1989/1990. Food and feeding ecology of Mastacembelus armatus (Lecep.) from Gadigarh stream, Jammu. Matsya 15, 16: 66-69.

Fisher R.A. 1970. Statistical methods for research workers. 14th edn. Oliver and Boyd, Edinburgh.

Froese R., Binohlan C. 2000. Empirical relationships to estimate asymptotic length, length at first maturity and length at maximum yield per recruit in fishes, with a simple method to evaluate length frequency data. Journal of Fish Biology 56: 758-773.

Froese R., Pauly D. (eds) 2006. FishBase, World-wide Web Electronic Publication. http://www.fishbase.org

Grimes C.B., Huntsman G.R. 1980. Reproductive biology of the vermilion snapper, Rhomboplites aurorubens from North Carolina and South Carolina. Fishery Bulletin 78: 137-146. 
Hart T.J. 1946. Report on the trawling surveys on the Patagonian continental shelf. "Discovery" Reports 23: 223-408.

Hickling C.F., Rutenberg E. 1936 . The ovary as an indicator of spawning period in fishes. Journal of the Marine Biological Association of the United Kingdom 21: 311-317.

June F.C. 1953. Spawning of yellowfin tuna in Hawaiian waters. Fishery Bulletin 54: 47-64.

Kagwade V.N. 1968. Maturation and spawning of the horse mackerel Caranx kalla (Cuv. and Val.). Indian Journal of Fisheries 15: 207-220.

Karim M.A., Hossain A. 1972. Studies on the biology of Mastacembelus pancalus (Ham.) in artificial ponds. Part II. Sexual maturity and fecundity. Bangladesh Journal of Biology and Agricultural Sciences 1: 15-18.

Lagler K.F. 1956. Freshwater fishery biology. 2nd edn. W.C. Brown Co., Dubuque, IA, USA.

Le Cren E.D. 1951. The length-weight relationship and seasonal cycle in gonad weight and condition in the perch (Perca fluviatilis). Journal of Animal Ecology 21: 210-219.

Menon M.D. 1950. The bionomics of the poor cod (Gadus minutus L.) in the Plymouth area. Journal of the Marine Biological Association $\mathrm{f}$ the United Kingdom 29: 195-239.

Qayyum A., Qasim S.Z. 1964. Studies on the biology of some fresh water fishes. Part II. Barbus stigma (Cuv. and Val.). Journal of the Bombay Natural History Society 61: 330-347.

Serajuddin M. 2004. Intraspecific diversity of riverine populations of spiny eel, Mastacembelus armatus. Applied Fisheries and Aquaculture 4: 25-29.

Serajuddin M., Mustafa S. 1994. Feeding specialization in adult spiny eel, Mastacembelus armatus. Asian Fisheries Science 7: 63-65.
Serajuddin M., Khan A.A., Mustafa S. 1998. Food and feeding habits of the spiny eel, Mastacembelus armatus. Asian Fisheries Science 11: 271-278.

Serajuddin M., Ali R. 2005. Food and feeding habits of striped spiny eel, Macrognathus pancalus (Hamilton). Indian Journal of Fisheries 52 (1): 81-86.

Sugunan V.V., Mitra K, Vinci G.K. 2002. Ornamental fishes of West Bengal. Classic Printers, Kolkata, India.

Swarup K., Srivastava S., Das V.K. 1972. Sexual dimorphism in the spiny eel, Mastacembelus pancalus. Current Science 41 (2): 68-69.

Talwar P.K. 1962. A contribution to the biology of the halfbeak, Hyporhamphus georgii (Cuv. \& Val.) (Hemirhamphidae). Indian Journal of Fisheries 9: 168-196.

Talwar P.K., Jhingran A.G. 1991. Inland fishes of India and adjacent countries. Vol. 2. Oxford and IBH Publishing, New Delhi, Bombay, Calcutta.

Tripathi S.D. 2004. Ornamental fishes: Breeding, culture and trade. Pp.17-42. In: Das R.C., Sinha A., Datta S., Ghosh S. (eds). Proceedings of the National Seminar on Prospects of Ornamental Fish Breeding and Culture in Eastern and Northeastern India. Central Institute of Fisheries Education, (Indian Council of Agricultural Research), Kolkata, India.

Varghese T.J. 1961. Observations on the biology of Raconda russelliana (Gray). Indian Journal of Fisheries 8: $96-106$. 